\title{
INVESTIGATING THE ROLE OF JOB SATISFACTION: DOES IT ACT AS A MODERATOR OR MEDIATOR BETWEEN ORGANIZATIONAL IDENTIFICATION AND WORK ENGAGEMENT?
}

Sevcan KILIÇ AKINCI ${ }^{1}$
Received Date (Başvuru Tarihi): 16/11/2018

Accepted Date (Kabul Tarihi): 17/12/2018

Published Date (Yayın Tarihi): 04/01/2019

\section{ABSTRACT}

This study extends Social Identity Theory by examining the link between organizational identification (OI) and work engagement (WE) through enhanced job satisfaction (JS) and testing it in a non-US environment, which makes contribution to the literature. The study was conducted on a large sample (527) of Turkish blue and white-collar employees from business units of 15 independent companies from 10 different industry types and data was analyzed with Structural Equation Modelling. The results showed that organizational identification is positively related with work engagement. Job satisfaction did not moderate the relationship between OI and WE, but it mediated $54 \%$ of the effect of OI and thus, confirmed the applicability of Social Identitiy Theory in a Turkish context. Results revealed that a sense of identification may be a precondition for work engagement; but it is the mediating effect of job satisfaction, which enhances this relationship.

Keywords: Work Engagement, Job Satisfaction, Organizational Identification, Social Identity Theory, Turkey

JEL Codes : M10, J28, J24

\section{ISS TATMINİ ÖRGÜTSEL KIMLIK VE İŞE TUTKUNLUK ARASINDA ARACI DEĞISSTEN OLARAK MI DÜZENLEYICII DEĞIŞSEN OLARAK MI ROL ALMAKTADIR?}

$\ddot{O} Z$

Bu çalışma, artan iş doyumunun örgütsel kimlik ve işe tutkunluk arasındaki ilişkiye etkisiniSosyal Kimlik Teorisi bağlaminda incelemekte ve bu ilişkiyi $A B D$ dışında bir çevrede test ederek literatüre katkl sunmaktadır. Çalışma 10 farklı endüstride faaliyet gösteren 15 işletmeden beyaz ve mavi yakalı toplam 527 çalışanı kapsayan geniş bir örneklem üzerinde test edilmiş ve veriler Yapısal Eşitlik Modellemesi ile analiz edilmiştir. Bulgular, örgütsel kimliğin işe adanma ile pozitif ilişskili olduğunu göstermiştir. İş doyumu örgütsel kimlik ile işe adanma arasındaki ilişkiyi düzenleyici değişken olarak yer almamış, aracı değişken olarak ilişkinin \%54'ünü açıklamış ve böylece Sosyal Kimlik Teorisinin Türkiye'deki bir örneklem üzerinde geçerli olduğunu ispatlamıştır. Sonuçlar, kimlik hissinin işe adanma konusunda bir ön koşul olduğunu fakat bunu güçlendiren değişkenin iş doyumu olduğunu göstermişstir.

Anahtar Kelimeler: İşe Tutkunlık, İş Tatmini, Örgütsel Kimlik, Sosyal Kimlik Teorisi, Türkiye

JEL Kodlart: M10, J28, J24

${ }^{1}$ Dr. Öğrt. Üyesi, Erzurum Teknik Üniversitesi, sevcan.akinci@erzurum.edu.tr 


\section{INTRODUCTION}

In today's highly competitive work environment, firms strive for achieving several ways of gaining competitive advantages over rivals through work engagement (WE).Empirical research shows that there is a positive relationship between WE and job satisfaction (JS) in different professions. Our study contributes to the on-going debate on the relationship between JS and WE in organizations, through examination of Organizational Identification (OI)'s effect on the mentioned relationship, in Turkish context. This paper makes two specific contributions. Firstly, this is the first study that examines the effect of OI on WE, through enhanced JS in Turkish context. Secondly, whether JS acts as a mediator or moderator on the relationship between OI and WE is tested and thus, Social Identitiy Theory (SIT) is extended. As methodological advantage of the paper, to evaluate internal validity, it is preferred to use Mc Donald's Omega coefficient besides Cronbach alpha. Omega is selected deliberately because it is specifically developed for evaluating internal consistency in exploratory and confirmatory factor analysis, and in Structural Equational Models where latent variables exist. Since exploratory and confirmatory factor analysis are applied in variable selection and Structural Equational Modelling, where latent variables exist for mediator and moderator analysis, McDonald's Omega is preferred to be used.

\subsection{Work Engagement}

Engagement at work was conceptualized by Kahn (1990), as the 'harnessing of organizational members' selves to their work roles'. Similarly, according to Van Bogaert et.al (2013), work engagement is a combination of the capability to work (energy, vigour) and the willingness to work (involvement, dedication). In academic literature, work engagement is often characterized with the amount of discretionary effort exhibited by employees in their jobs (Frank et al., 2004) or emotional and intellectual commitment to the organization (Baumruk, 2004; Richman, 2006; Shaw, 2005). A highly engaged employee will consistently deliver beyond expectations (Wright \&Cropanzano, 2000). Although generally "employee engagement" and "work engagement" are used interchangeably, as Schaufeli and Bakker (2010) states the former is more general and has connections with the organization itself. Work engagement refers to the relationship of the employee with his or her work, whereas employee engagement may also include the relationship with the organization. 


\subsection{Job Satisfaction}

Job satisfaction is one of the most researched concepts in academic literature, since it has practical positive work-related outcomes for businesses besides its strong theoretical base. The three most common definitions of JS describe it as: "the pleasurable emotional state resulting from the appraisal of one's job as achieving or facilitating the achievement of one's job values (Locke, 1976), "the extent to which people like (satisfaction) or dislike (dissatisfaction) their jobs" (Spector, 2006) and "all the feelings that an individual has about his/her job" (Spector, 1997). It is 'a positive (or negative) evaluative judgment that is made by one, about one's job or job situation' (Weiss, 2002). In other words, job satisfaction has emotional, cognitive, and behavioral components (Bernstein \& Nash, 2008; Rich et al., 2010). Academic literature, which focuses on behavioral aspect of JS, reports that high JS is associated with higher levels of job performance, organizational citizenship behavior, lower levels of turnover (Hulin \& Judge, 2003), loyalty and counterproductive behavior (Gottfredson \& Holland, 1990). In this research, researchers will use the concept of JS developed by Spector (1997).

\subsection{Association of Job Satisfaction and Work Engagement}

The relationship between JS and WE has been widely researched. However, the direction of the relationship between JS and WE remains unclear in the literature (Mauno, Kinnunen \& Ruokolainen, 2006; Bakker \& Schaufeli, 2008; Schaufeli \& Bakker, 2010). Overwhelming of studies argue that JS is a predictor of work engagement (Avery, Kay \& Wilson, 2007; Simpson, 2009; Salanova, Llorens \& Schaufeli, 2011; Yalabik et al., 2013; Harter, Schmidt \& Hayes, 2002). Abraham (2012) links WE with JS and defines it as the degree to which workers feel JS and an emotional connection to the success of their business, resulting in improved productivity, innovation and retention, which is the basic proposition of our study. Maylett \& Riboldi (2008) states that JS is a component of making an employee feel engaged. Similarly, Tiwari (2011) in a study has cited JS as an antecedent to WE; Robinson, Perryman \& Hayday (2004) and Penna (2005) all use a model of engagement which incorporates JS, as one of key influences on staff engagement and overall satisfaction at work. Also, the results of 2012 Employee Engagement published by SHRM reveals that the conditions of WE are related to the factors influencing JS in an organization (Abraham, 2012). In the light of previous research, we expect that the employees who are satisfied with their jobs, become engaged and produce positive outcomes for both the work and organization. 


\subsection{Organizational Identification and Social Identity Theory (SIT)}

Organizational identification (OI) is defined as "a psychological linkage between the individual and the organization whereby the individual feels a deep, self-defining affective and cognitive bond with the organization as a social entity" (Edwards \& Peccei, 2007).

The dominant theory that most of the OI studies are based, is Social Identity Theory (SIT), which states that OI is commonly believed to develop as a result of the group to which the individual belongs; thus, the individual-group relationship should be analyzed in this framework (Tajfel, 1982). SIT proposes that individuals seek to join and sustain membership in groups that reinforce their self concepts (Tajfel\& Turner, 2004).

We see the first detailed model of OI was proposed by March and Simon (1958). Since then compared with other psychological variables, which are relevant to work behavior, such as job satisfaction and work motivation; organizational identification (OI) has received little attention until recently. Firms seek to achieve identification since as the result of identification, positive outcomes such as greater job satisfaction, lower rate of absenteeism, greater cooperative behavior and lower turnover are achieved (Riketta, 2005; Van Dick et al., 2004). A sense of identification may be a precondition for job satisfaction and it may prevent employees from being alienated (Dutton et al., 1994). It induces individuals to engage in the work and derive satisfaction from activities that fit to the identity (Ashforth \& Mael, 1989).

\subsection{Previous Research}

In academic literature, vast majority of the researchers found evidence that employees' levels of engagement predict positive outcomes for organization (Salanova, Agut \& Peiro, 2005; Schaufeli et.al., 2002) and engaged employees are more likely to exhibit discretionary efforts and improve individual performance (Van Bogaert et.al., 2013).

Although a high level of organizational identification can yield desirable results for both organizations and individuals (Boroş, 2008), research on its relationship with work-related attitudes, such as job satisfaction and on the mechanisms governing this relationship, is in the very early stages of development (Karanika-Murray et.al., 2015).

In academic literature, research on direct link between work engagement and organizational identification is scarce. Cartwright \& Holmes (2006) recommends further research on engagement and identification; Karanika-Murray et.al. (2015) published a recent research on the link between the two. 
For Turkish setting, to the best knowledge of researchers there is only one study. Ötken \& Erben (2010) also studied OI and WE relationship on 212 employees working in private sector in Turkey. They reported that employees who identify with their organization have high levels of work engagement. Support, received from supervisor, is found to have a moderating role in this relationship. Gümüş et.al. (2012), reported that both occupational and organizational identification had reverse effect on intention to early retirement and both categories had positive effect on job satisfaction.

In light of the above suggestions, the aim of the present study is to investigate the effect of organizational identification (being a member of the organization) on work-related outcomes, namely work engagement through enhanced satisfaction of the personnel.

\section{MATERIALS AND METHOD}

Although a lot of studies on the sources and consequences of work engagement have been already carried out, there is still space for exploration of its relationship with different antecedents. In this study, drawing from SIT, we develop and test a model whereby OI is linked to WE through enhanced JS and thus we test whether JS acts as mediator or moderator over WE or not.

Several facts have been taken into account when developing the study. First, overall job satisfaction has been included as a potential predictor of work engagement and moderation and mediation effects of it over WE, are researched. Second, the suggested theoretical approach grounded in work engagement construct, has been utilized. Third, OI, as a congruent measure of work engagement, has been used. Fourth, a large sample from various work settings has been included. A large sample (527) of Turkish blue and white-collar employees from business units of 15 independent companies from 10 different industry types have been taken as population of the study.

\subsection{Model and Hypothesis}

In the light of literature review, our paper proposes that OI determines individual's attitudes toward his or her job and determines specifically his or her engagement through enhanced job satisfaction. Therefore, following hypothesis were tested.

Hypothesis 1: Organizational Identification (OI) is (positively) related to WE

Hypothesis 2: Organizational Identification (OI) determines an individual's attitudes toward his job, and specifically work engagement, which is moderated by job satisfaction. 
Hypothesis 3: Job Satisfaction (JS) mediates the positive relationship between Organizational Identification (OI) and Work Engagement (WE), such that OI is positively related to JS which is, in turn, positively related to WE.

527 questionnaires were filled in by respondents and were ready to be analyzed. Mean age of the sample was 31,318 men and 209 women. This is due to the fact that female employees are still rare in the industry. Mean tenure of the sample was 6,98 years. In terms of educational background, $29 \%$ had high school degree, $47 \%$ of the sample had undergraduate degree; $20 \%$ had associate degree, and $3 \%$ had graduate degrees.

WE was measured with The Utrecht Work Engagement Scale developed by Dr. Wilmar B. Schaufeli et.al. (2002). Participants responded using a 7-point Likert scale with anchors (0) never to (6) always. The reliability and the factorial validity of the UWES have been supported by Schaufeli et al. (2002). For OI, the measure developed by Mael \& Asforth (1992) was used. Cronbach alpha coefficient of the measure was stated by Mael \& Ashforth (1992) as ,07. Back to back translation of both measures were done. After a pilot test on 32 academicians, the measures were used in this study.

\subsection{Data Analysis and Findings}

To analyze the data, R-Project program (R Core Team, 2018), Psych package (Revelle, 2018) and SmartPLS 3.0 (Ringle, Wende, \& Will, 2015) was used.

Firstly, an iterative "item trimming" procedure was performed for the original scale items and following that Cronbach Alpha was calculated as 0,95 and total Omega was calculated as 0,97 . When deciding if the data set was suitable for PCA, Kaiser-Meyer-Olkin (KMO) Measure of Sampling Adequacy Index was calculated. KMO index was found as 0,94, which proved marvelous for PCA as Kaiser (1974) recommended.

Than mediator and moderator analysis was performed by using SmartPLS program. Firstly, direct effect of OI over WE was tested. For OI.5VIF values was found to be 5,014 (>5), it was iscarded from model and analysis continued. 


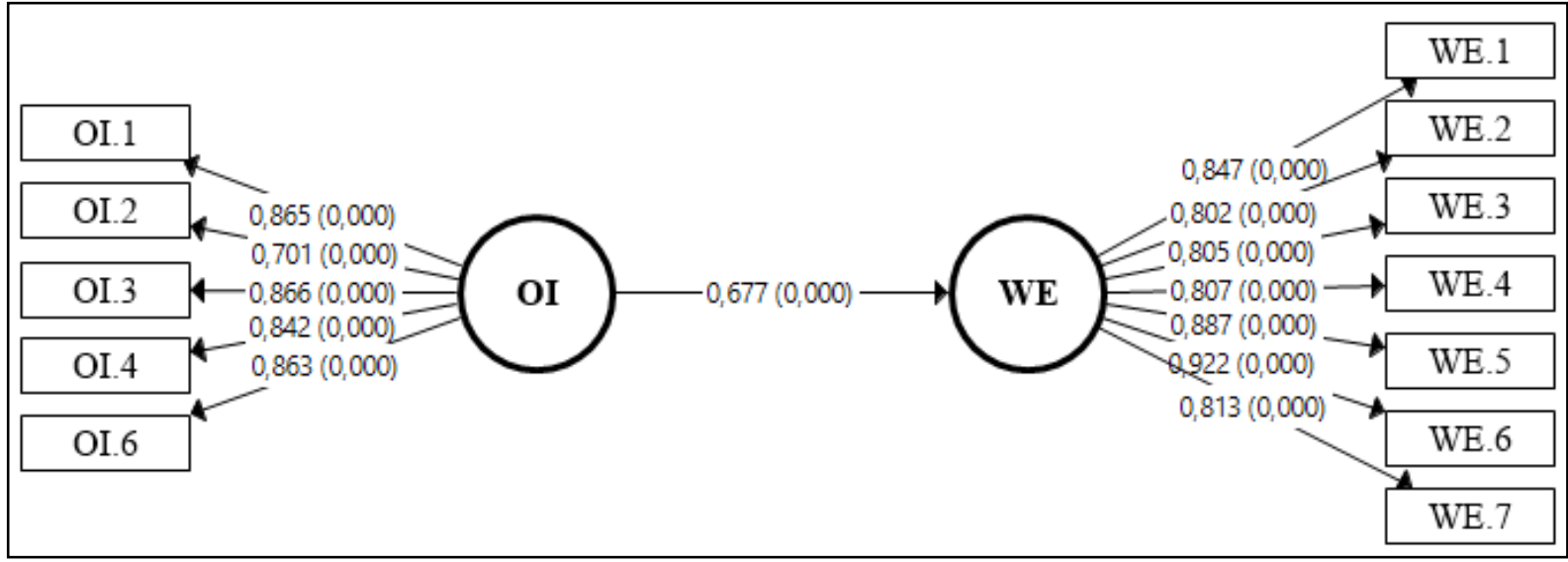

Figure 1: OI's direct effect on WE

For model fit, SRMR value was calculated as 0,052 which is smaller than the critical values of 0,08 and NFI value was calculated to be as 0,90 , which was equal to the critical value. These values showed that model was acceptable.

OI's direct effect over WE was calculated as 0,677 ( $p$ value:0,000) which showed that it was significant. The bootstrapping value of effect size of $\mathrm{f}^{2}$ was calculated as 0,872 ( $p$ value:0,000) large $(0,35+)$. Thus, our first hypothesis was found acceptable.

To test mediation effect, JS was added to the model as mediator.

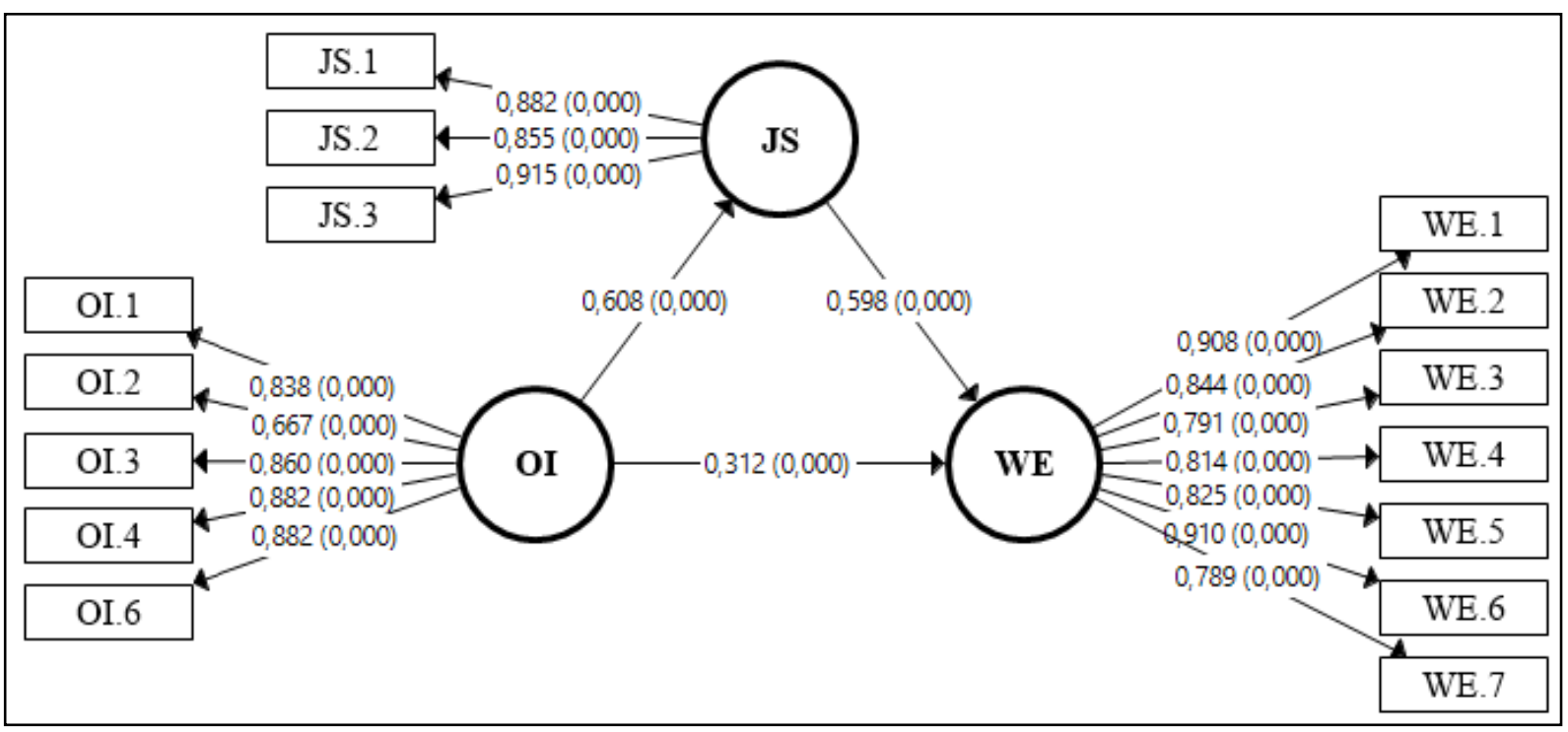

Figure2: JS's Mediation Effect On The Relationship Of OI And WE

To research the mediation effect of JS, firstly SRMR and NFI values were analyzed for model fit. For model fit SRMR value 0,047, which was smaller than critical value of 0,08 and NFI value was calculated as 0,880 , which was nearly equal to 0,90 . In other words, when JS was added to the model as mediator, the model was found to be acceptable. 
Path coefficient of JS's direct effect over WE was found to be significant 0,598 (p value: $0,000)$. The path coefficient of OI's direct effect over JS was found to be significant 0,608 with p value: 0,000 .

When JS was added to the model as mediator, the path coefficient of OI's direct relationship over WE decreased from 0,677 ( $p$ value:0,000) to 0,312 ( $\mathrm{p}$ value: 0,001 ). The rest of the effect, has shifted to OI's indirect effect over JS, which was found to be significant $(0,364 ; p$ value: 0,000$)$. As a result, it is evident that, when JS was added to the model, it mediated $54 \%$ of the effect of OI's. Thus our third hypothesis is accepted.

Bootstrapping results of effect size $\left(\mathrm{f}^{2}\right)$ is presented in the table below:

Table1: Bootstrapping Results Of Effect Size $\left(\mathrm{f}^{2}\right)$ Of Mediation Model

\begin{tabular}{crrrrr}
\hline & $\begin{array}{r}\text { Original } \\
\text { Sample }\end{array}$ & $\begin{array}{r}\text { Sample } \\
\text { Mean }\end{array}$ & $\begin{array}{r}\text { Standard } \\
\text { Deviation }\end{array}$ & T Statistics & P Values \\
\hline \hline OI -> WE & 0,192 & 0,200 & 0,063 & 3,062 & 0,002 \\
\hline JS -> WE & 0,707 & 0,724 & 0,148 & 4,768 & 0,000 \\
\hline OI -> JS & 0,587 & 0,597 & 0,120 & 4,884 & 0,000 \\
\hline
\end{tabular}

The effect size of OI over WE was calculated as 0,200 (p value: 0,002), which was “moderate" according to Cohen's (1988)f $\mathrm{f}^{2}$. Besides this, JS's effect size over WE was found to be 0,724 (p value: 0,000$)$, which was "large".

As a result, the OI's effect size over WE was large and significant $(0,872$ with $p$ value: 0,000). But when JS was added to the model as mediator, effect size decreased to 0,200 ( $\mathrm{p}$ value:0,002) which made it weak.

Consequently, we can say that JS acts as a mediator between OI and WE.

To test moderation effect, JS was added to the model as moderator. 


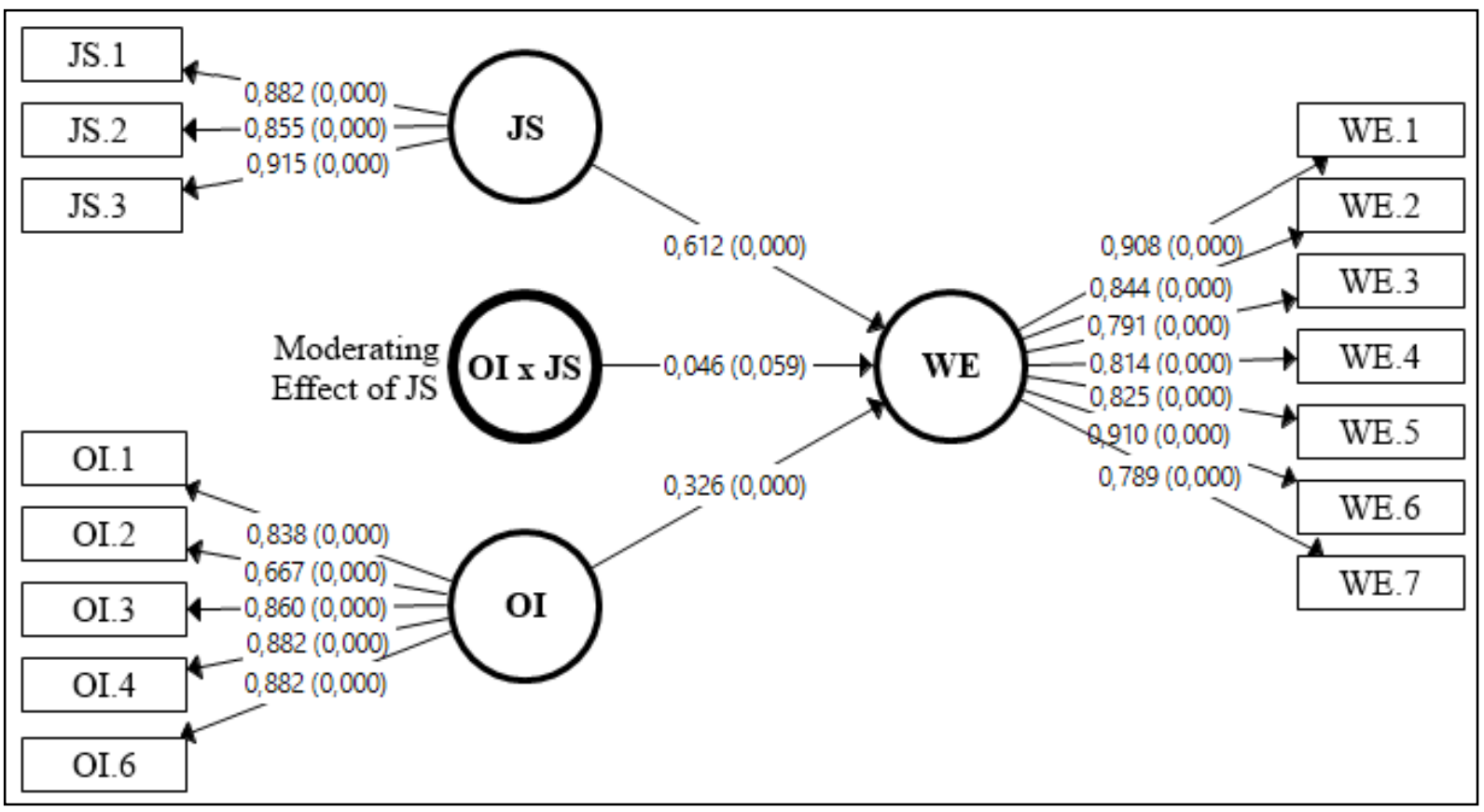

Figure3: JS's moderation effect on the relationship of OI and WE

To research the moderation effect of JS, firstly SRMR and NFI values are searched for model fit. For model fit SRMR value 0,047, which was smaller than critical value of 0,08 and NFI value was calculated as 0,887 which was nearly equal to 0,90 . In other words, when JS was added to the model as moderator, the model was found to be acceptable.

Path coefficient of JS's direct effect over WE was found to be significant 0,612 (p value:0,000). The path coefficient of OI's direct effect over JS was found to be significant 0,608 with $\mathrm{p}$ value: 0,000 . Path coefficient regarding moderating effect was found to be 0,046 (p value:0,058), which was insignificant. Thus our second hypothesis is rejected.

Bootstrapping results of effect size $\left(\mathrm{f}^{2}\right)$ is presented in the table below:

Table2: JS's Moderation Effect On The Relationship Of OI And WE

\begin{tabular}{crrrrr}
\hline & $\begin{array}{r}\text { Original } \\
\text { Sample }\end{array}$ & $\begin{array}{r}\text { Sample } \\
\text { Mean }\end{array}$ & $\begin{array}{r}\text { Standard } \\
\text { Deviation }\end{array}$ & TStatistics & P Values \\
\hline \hline OI -> WE & 0,204 & 0,211 & 0,064 & 3,164 & 0,002 \\
\hline JS -> WE & 0,718 & 0,740 & 0,160 & 4,482 & 0,000 \\
\hline Moderating Effect -> WE & 0,010 & 0,012 & 0,011 & 0,887 & 0,375 \\
\hline
\end{tabular}

OI's effect size over WE was 0,211 ( $\mathrm{p}$ value:0,002) and large. JS's effect over WE was 0,740 ( $\mathrm{p}$ value: 0,000 ) and was large also. 
It is evident that OI's effect size over WE was "large" and significant as of 0,872 (p value:0,000). But when JS was added to the model as a moderator, the effect size of OI over WE decreased to 0,211 (p value:0,002), which was "moderate" according to Cohen's (1988) classification; however, it is worth to note that the decrease from 0,872 to 0.211 made the effect size weaker. Moreover, moderating effect's effect size was calculated as 0,012 , which denoted "no effect" and $p$ value was 0,375 , which showed insignificance. As a result, it is evident that JS did not act as a moderator between the relationship of OI and WE.

\section{DISCUSSION}

Grounded on SIT, this study endeavored to investigate the association between OI and WE and thus, it contributes to limited research in collectivist societies pertaining to the effect of OI on WE. It is documented in academic literature that, individuals who have strong organizational identification with their organizations are more likely to be actively involved in achieving organization's goals and activities.

However, the effect of job satisfaction in engagement process is important and tested in this research. A sense of identification may be a precondition for work engagement; but results revealed that it is the mediating effect of job satisfaction, which enhances this relationship.

Results of the study revealed that JS does not act as a moderator but it acts as a mediator between the OI and WE for paid jobs. The findings of this research revealed and supported the previous findings about job satisfaction's positive effect on WE.

In reality, satisfaction is barely minimum. Job satisfaction keeps employees around but it doesn't really inspire them to do more than to fulfill the fundamental job requirements and their role. A satisfied but unengaged employee generally enjoys what he does for a living, but for the most part, his job is a means for a paycheck. As he probably isn't complaining about it too much, and he/she completes his/her tasks as assigned and is likely willing to work more hours as necessary, he's still productive and valuable members of the workforce. But to go beyond the basic responsibilities outlined in his job description or pitching ideas to upper management about ways to improve the organization, the personnel should be engaged to his/her work. One way to ensure this, organizational identification. Organizations need to ensure that their employees identify themselves with the organization. Having satisfied employees who perform better and who identify themselves with their work, helps to foster engagement. 


\section{REFERENCES}

Abraham, S. (2012). Job Satisfaction as an Antecedent to Employee Engagement. SIES Journal of Management, $8(2), 27-36$.

Ashforth, B. E., \& Mael, F. (1989). Social Identity Theory and the Organization. Academy of Management Review, 14(1), 20-39. https://doi.org/10.5465/amr.1989.4278999

Avery, D. R., McKay, P. F., \& Wilson, D. C. (2007). Engaging the Aging Workforce: The Relationship Between Perceived Age Similarity, Satisfaction With Coworkers, and Employee Engagement. Journal of Applied Psychology, 92(6), 1542-1556. https://doi.org/10.1037/0021-9010.92.6.1542

Bakker, A. B., \& Schaufeli, W. B. (2008). Positive Organizational Behavior: Engaged Employees in Flourishing Organizations. Journal of Organizational Behavior, 29(2), 147-154. https://doi.org/doi:10.1002/job.515

Baumruk, R. (2004). The Missing Link : The Role of Employee Engagement in Business Success. Workspan; ABI/ INFORM, 47, 48-52. https://doi.org/10.1007/s13398-014-0173-7.2

Bernstein, D. A., \& Nash, P. W. (2008). Essentials of Psychology. Boston, MA: Houghton Mifflin.

Boroş, S. (2008). Organizational Identification: Theoretical and Empirical Analyses of Competing Conceptualizations. Cognitie, Creier, Comportament / Cognition, Brain, Behavior, 12(1), 1-27.

Cartwright, S., \& Holmes, N. (2006). The Meaning of Work: The Challenge of Regaining Employee Engagement and Reducing Cynicism. Human Resource Management Review, 16(2), 199-208. https://doi.org/10.1016/j.hrmr.2006.03.012

Cohen, J. (1988). Statistical Power Analysis for the Behavioral Sciences. Hillsdale, N.J., US: Lawrence Erlbaum Associates.

Dutton, J. E., Dukerich, J. M., \& Harquail, C. V. (1994). Organizational Images and Member Identification. Administrative Science Quarterly, 39(2), 239. https://doi.org/10.2307/2393235

Edwards, M. R., \& Peccei, R. (2007). Organizational Identification: Development and Testing of a Conceptually Grounded Measure. European Journal of Work and Organizational Psychology, 16(1), $25-57$. https://doi.org/10.1080/13594320601088195

Frank, F., Finnegan, R., \& Taylor, C. (2004). The Race for Talent: Retaining and Engaging Workers in the 21st Century. Human Resource Planning, 27(3), 12-25.

Gottfredson, G. D., \& Holland, J. L. (1990). A Longitudinal Test of the Influence of Congruence: Job Satisfaction, Competency Utilization, and Counterproductive Behavior. Journal of Counseling Psychology, 37(4), 389-398. https://doi.org/10.1037/0022-0167.37.4.389

Gümüş, M., Hamarat, B., Çolak, E., \& Duran, E. (2012). Organizational and Occupational Identification: Relations to Teacher Satisfaction and Intention to Early Retirement. Career Development International, 17(4), 300313. https://doi.org/10.1108/13620431211255806

Harter, J. K., Schmidt, F. L., \& Hayes, T. L. (2002). Business-Unit-Level Relationship between Employee Satisfaction, Employee Engagement, and Business Outcomes A Meta-Analysis. Journal of Applied Psychology, 87(2), 268-279. https://doi.org/10.1037/0021-9010.87.2.268

Hulin, C. L., \& Judge, T. A. (2003). Job Attitudes. In W. C. Borman, D. R. Ilgen, \& R. Klimoski (Eds.), Handbook of Psychology, Volume 12: Industrial and Organizational Psychology (pp. 255-276). New Jersey, US: John Wiley \& Sons Inc. https://doi.org/doi:10.1002/0471264385.wei1211

Kahn, W. A. (1990). Psychological Conditions of Personal Engagement and Disengagement at Work. Academy of 
Management Journal, 33(4), 692-724. https://doi.org/10.2307/256287

Kaiser, H. F. (1974). An Index of Factorial Simplicity. Psychometrika, 39(1), 31-36. https://doi.org/10.1007/BF02291575

Karanika-Murray, M., Duncan, N., Pontes, H. M., \& Griffiths, M. D. (2015). Organizational Identification, Work engagement, and Job Satisfaction. Journal of Managerial Psychology, 30(8), 1019-1033. https://doi.org/10.1108/JMP-11-2013-0359

Locke, E. A. (1976). The Nature and Causes of Job Satisfaction. In Handbook of Industrial and Organizational Psychology (pp. 1297-1350). Chicago, US: Rand McNally College Pub. Co.

Mael, F., \& Ashforth, B. E. (1992). Alumni and Their Alma Mater: a Partial Test of the Reformulated Model of Organizational Identification. Journal of Organizational Behavior, 13(2), 103-123. https://doi.org/10.1002/job.4030130202

March, J. G., \& Simon, H. A. (1958). Organizations. New York, US: Wiley.

Mauno, S., Kinnunen, U., \& Ruokolainen, M. (2006). Exploring Work- and Organization-Based Resources as Moderators Between Work-Family Conflict, Well-Being, and Job Attitudes. Work \& Stress, 20(3), 210233. https://doi.org/10.1080/02678370600999969

Maylett, T. M., \& Riboldi, J. M. (2008). The Three Essential Components of Employee Engagement (Whitepaper). Retrieved from https://tr.scribd.com/document/66411061/Decision-Wise-Whitepaper-3-EssentialComponents-of-Employee-Engagemen

Ötken, A. B., \& Erben, G. S. (2010). Investigating the Relationship Between Organizational Identification and Work Engagement and the Role of Supervisor Support. Gazi Üniversitesi Iktisadi ve İari Bilimler Fakültesi Dergisi, 12(2), 93-118.

Penna. (2005). Meaning at Work (Research Report - Coord. Trevor Lambert). London, UK. Retrieved from https://www.ciodevelopment.com/wp-content/uploads/2011/10/2006-10-08-08-36-31_Penna-Meaningat-Work-Report.pdf

R Core Team. (2018). R: A Language and Environment for Statistical Computing. R Foundation for Statistical Computing. Vienna, Austria. Retrieved from http://www.r-project.org/

Revelle, W. (2018). psych: Procedures for Psychological, Psychometric, and Personality Research. Northwestern University. Evanston, Illinois, US. Retrieved from https://cran.r-project.org/package=psych

Rich, B. L., Lepine, J. A., \& Crawford, E. R. (2010). Job Engagement: Antecedents and Effects on Job Performance. Academy of Management Journal, 53(3), 617-635. https://doi.org/10.5465/amj.2010.51468988

Richman, A. (2006). Everyone Wants an Engaged Workforce How Can You Create It. Workspan, 49(1), 36-39.

Riketta, M. (2005). Organizational identification: A meta-analysis. Journal of Vocational Behavior, 66(2), 358384. https://doi.org/10.1016/J.JVB.2004.05.005

Ringle, C. M., Wende, S., \& Will, A. (2015). Smart PLS. SmartPLS GmbH. Bönningstedt, DE. Retrieved from http://www.smartpls.de

Robinson, D., Perryman, S. P., \& Hayday, S. (2004). IES Report 408: The Drivers of Employee Engagement. . Institute for Employment Studies Report. Brighton, UK : Institute for Employment Studies. Retrieved from https://www.employment-studies.co.uk/system/files/resources/files/408.pdf

Salanova, M., Agut, S., \& Peiró, J. M. (2005). Linking Organizational Resources and Work Engagement to 
Employee Performance and Customer Loyalty: The Mediation of Service Climate. Journal of Applied Psychology. https://doi.org/10.1037/0021-9010.90.6.1217

Salanova, M., Llorens, S., \& Schaufeli, W. B. (2011). “Yes, I Can, I Feel Good, and I Just Do It!” On Gain Cycles and Spirals of Efficacy Beliefs, Affect, and Engagement. Applied Psychology, 60(2), 255-285. https://doi.org/10.1111/j.1464-0597.2010.00435.X

Schaufeli, W. B., \& Bakker, A. B. (2010). Defining and Measuring Work Engagement: Bringing Clarity to the Concept. In A. B. Bakker \& M. P. Leiter (Eds.), Work Engagement: A Handbook of Essential Theory and Research (pp. 10-24). New York, NY, US: Psychology Press, Taylor \& Francis Group. https://doi.org/10.4324/9780203853047

Schaufeli, W. B., Salanova, M., González-Romá, V., \& Bakker, A. B. (2002). The Measurement of Engagement and Burnout: A Two Sample Confirmatory Factor Analytic Approach. Journal of Happiness Studies: An Interdisciplinary Forum on Subjective Well-Being, 3(1), 71-92. https://doi.org/10.1023/A:1015630930326

Shaw, K. (2005). An Engagement Strategy Process for Communicators. Strategic Communication Management, 9(3), 26-29.

Simpson, M. R. (2009). Predictors of Work Engagement Among Medical-Surgical Registered Nurses. Western Journal of Nursing Research, 31(1), 44-65. https://doi.org/10.1177/0193945908319993

Spector, P. E. (1997). Job Satisfaction: Application, Assessment, Causes, and Consequences. California, US: SAGE Publications, Inc. https://doi.org/10.4135/9781452231549

Spector, P. E. (2006). Method Variance in Organizational Research. Organizational Research Methods, 9(2), 221232. https://doi.org/10.1177/1094428105284955

Tajfel, H. (1982). Social Psychology of Intergroup Relations. Annual Review of Psychology, 33(1), 1-39. https://doi.org/10.1146/annurev.ps.33.020182.000245

Tajfel, H., \& Turner, J. C. (2004). The Social Identity Theory of Intergroup Behavior. In J. T. Jost \& J. Sidanius (Eds.), Political Psychology (In Series of Key Readings in Social Psychology) (pp. 276-293). New York, NY, US: Psychology Press.

Tiwari, S. (2011). Employee Engagement - The Key to Organizational Success. In 10th International Conference on Operations and Quantitative Management (pp. 311-328). Nashik, India.

Van Bogaert, P., Clarke, S., Willems, R., \& Mondelaers, M. (2013). Staff Engagement as a Target for Managing Work Environments in Psychiatric Hospitals: Implications for Workforce Stability and Quality of Care. Journal of Clinical Nursing, 22(11-12), 1717-1728. https://doi.org/10.1111/j.1365-2702.2012.04341.x

Van Dick, R., Christ, O., Stellmacher, J., Wagner, U., Ahlswede, O., Grubba, C., ... Tissington, P. A. (2004). Should I Stay or Should I Go? Explaining Turnover Intentions with Organizational Identification and Job Satisfaction. British Journal of Management, 15(4), 351-360. https://doi.org/10.1111/j.14678551.2004.00424.x

Weiss, H. M. (2002). Deconstructing Job Satisfaction: Separating Evaluations, Beliefs and Affective Experiences. Human Resource Management Review, 12(2), 173-194. https://doi.org/10.1016/S1053-4822(02)000451

Wright, T. A., \& Cropanzano, R. (2000). Psychological Well-Being and Job Satisfaction as Predictors of Job Performance. Journal of Occupational Health Psychology, 5(1), 84-94. https://doi.org/10.1037/1076- 
8998.5.1.84

Yalabik, Z. Y., Popaitoon, P., Chowne, J. A., \& Rayton, B. A. (2013). Work Engagement as a Mediator Between Employee Attitudes and Outcomes. The International Journal of Human Resource Management, 24(14), 2799-2823. https://doi.org/10.1080/09585192.2013.763844 